\title{
Monika Białek
}

Uniwersytet Gdański

\section{Dźwiękowa identyfikacja bohaterów w reportażu radiowym}

\begin{abstract}
Streszczenie
Niewidzialność przekazu radiowego implikuje dodatkowe wrażenia o charakterze innym niż audialny. Dzieło foniczne, u tym także reportaż radiouy, pobudza nie tylko słuch, ale przede uszystkim uyobraźnię dźwiękową odbiorcy. O sukcesie artystycznego przekazu radiouego można mówić tylko u sytuacji, gdy percepcji słuchowej towarzyszyć będą obrazy skojarzeniowe. Są one niezbędne do odczytania przekazu i właściwej identyfikacji postaci. W artykule zaprezentowano różne sposoby dźuiękowej prezentacji bohaterów. Foniczne oznaczenie postaci może odbyć się poprzez uykorzystanie wypowiedzi innych uczestników reportażu, a także poprzez uypowiedź reportera. Autor może róunież dokonać formalnej prezentacji, wykorzystując przy tym techniki typowe dla dziennikarstwa informacyjnego lub uciekając się do stylizacji, podporządkouując konwencji identyfikację bohatera. Najczęściej jednak uczestnicy reportażu pozostają anonimowi, dookreślani poprzez okoliczności towarzyszące.
\end{abstract}

Słowa kluczowe: radio, reportaż, dokument radiowy, Polskie Radio.

\section{Auditory identification of characters in radio reportages}

\begin{abstract}
Apart from auditory impressions, the invisibility of radio messages implies additional stimuli. Phonic works, radio reportages included, stimulate not only the sense of hearing, but also the auditory imagination of their audiences. An artistic radio message may be perceived as successful only if the auditory perception is accompanied by associative images. They are essential for the proper comprehension of messages and identification of characters. The article presents various forms of auditory presentation of characters. Particular individuals may be phonically designated in the utterances made by other people depicted in the reportage, as well as by the reportage makers themselves. The author can also present them formally, using techniques typical for news journalism, or through the use of style, by subjecting the identification process to the convention. Most often however, the characters remain anonymous and are specified only by the accompanying events.
\end{abstract}

Key words: radio, reportage, radio document, Polish Radio.

Reportaż radiouy operuje dźwiękami. To stwierdzenie wydaje się banalne w suojej oczywistości, jednak materia dźwiękowa, charakteryzująca się niewidzialnością, wymaga od autora dużej urażliwości i wyczucia audialnego. Przekaz radiowy w swojej istocie 
jest awizualny. Dlatego radiowiec musi nauczyć się korzystać z akustycznych środków wyrazu tak, aby wywołać ułaściwe obrazy skojarzeniowe u odbiorcy. Jak zauważa Wojciech Markiewicz:

Ślepota radia ma swoje ewidentne plusy. W epoce cywilizacji obrazków i komiksów (czyli skrótu myślowego) radio rozwija wyobraźnię. [...] Szczegóły radiowego procesu komunikacji musi stuarzać sam odbiorca. Obraz dźwiękouy odwołuje się bowiem do naszego dośuiadczenia życiowego. Chodzi jedynie o to [...], by zasugerować określony materiał pojęciouy, zebrać peuną ilość przykładów i dać podstawę do reinterpretacji powyższych zdarzeń akustycznych ${ }^{1}$.

Niewątpliwie na pełen obraz wyobrażeniowy słuchacza upływają między innymi jego urażliwość, dotychczasowe doświadczenie i uykształcenie. Z kolei rolą nadaucy, w tym przypadku autora reportażu, jest stworzenie zjawiska synestezji, które rozumiemy jako występowanie wrażeń zmysłowych towarzyszących bodźcowi działającemu na jeden tylko zmysł'. Oznacza to, że elementy pierwotnie wizualne pouinny zaistnieć w sferze audialnej, po to aby ponownie zyskać charakter przedstawieniouy. Jak zauważają badaczki z łódzkiej szkoły radioznawczej „owa skłonność do «uizualnej» aktualizacji znaczeń audialnych nie byłaby możliwa, gdyby urażenia słuchowe nie ewokowały wzrokowych, a więc gdyby materia foniczna nie kierunkowała wyobraźni odbiorcy na próbę odtworzenia sfery wizualnej”3.

Za pomocą dźwięków można wywołać u słuchacza konkretne obrazy skojarzenioue, przez uykorzystanie dźwięków - kluczy, które stają się metaforą przestrzenił. W tym przypadku awizualność przekazu radiowego można pokonać, a nawet wykorzystać do stworzenia fonosfery, która staje się tłem akustycznym zdarzeń. Jednakże wyzwaniem dla twórcy operującego tylko materią dźwiękową, staje się takie zaprezentowanie bohaterów, aby ich identyfikacja nie budziła wątpliwości.

Założeniem niniejszego artykułu jest prezentacja różnych sposobów uprowadzania i przedstawiania bohaterów radiouych opowieści. Zaznaczyć jednak należy, że terminy „bohater”, „postać”, „uczestnik” należy traktować synonimicznie. Jak zauważa Henryk Markiewicz: „[...] «bohater» posiada ograniczające konotacje bądź to «heroizmu», bądź to «pieruszoplanowości» [...]" ${ }^{5}$, natomiast przykłady przywołane $u$ artykule opisują także postacie drugoplanowe, wplecione w konflikt, będące świadkami lub badaczami

\footnotetext{
${ }^{1}$ H. Markiewicz, Radio, „Świat z dźwięków” [w:] Dziennikarstwo i świat mediów, red. Z. Bauer, E. Chudziński, Cracovia, Krakóu 1996, s. 70.

2 M. Gołaszeuska, Estetyka pięciu zmysłów, WN PWN, Warszawa-Kraków 1997, s. 19.

3 J. Bachura, A. Pawlik, Wtórna wizualność sztuki radiowej [w:] E. Pleszkun-Olejniczakowa, J. Bachura, A. Pawlik, Dwa teatry. Studia z zakresu teorii i interpretacji sztuki stuchowiskowej, Wydawnictuo Adam Marszałek, Toruń 2011, s. 447.

${ }^{4}$ Niektóre dźuięki tuorzą całą serię skojarzeń: tykanie - zegar - przemijanie; bicie dzwonu dzwon-trwoga - przestrzeń sakralna, zob. M. Białek, Polski reportaż radiowy. Wybrane zagadnienia, Wydawnictwo Naukowe Scriptorium, Poznań-Opole 2010, s. 93.

${ }^{5}$ H. Markiewicz, Wymiary dzieła literackiego, TAiWPN Universitas, Kraków-Wrocław 1984, s. 153.
} 
zdarzeń. Ponadto trzeba podkreślić, że poczynione tu rozważania stanowią opracowanie medioznawcze ( $w$ ujęciu praktycznym i teoretycznym), nie są, ani nie aspirują, do rozprawy językoznawczej. Materiałem badawczym stały się reportaże radiowe wyprodukowane i wyemitowane w Polskim Radiu po 1989 roku, czyli po transformacji ustrojowej i przeobrażeniu systemu medialnego w Polsce.

Po dokonaniu analizy współczesnych reportaży dźwiękouych ostatecznie można wyodrębnić trzy, wyraźnie wyróżniające się sposoby przedstawiania bohaterów radiouych opowieści: prezentacja wynikająca z wypowiedzi uczestników reportażu; prezentacja wynikająca z wypowiedzi reportera oraz prezentacja formalna. Osobną kategorię stanowi bohater anonimowy.

\section{Sposób prezentacji bohatera ${ }^{6}$}

Badaczka słuchowisk radiouych, Sława Bardijewska stuierdza, że:

Postać bohatera poustaje u słuchouisku zarówno w warstuie werbalno-pojęciouej, u oparciu o znaczenia słów, jak też w oparciu o dźwiękowy walor słowa i ekspresję fonicznej gry aktorskiej. Aktor rzeźbi postać słowem i własnym głosem, interpretując tekst i modelując jego sens suoistymi, indywidualnymi możliwościami głosouymi i całą osobowością, która za pomocą głosu się wyraża?.

Przytoczone spostrzeżenia odnoszą się do teatru radiowego. W przypadku reportażu radiowego nie możemy mówić o grze aktorskiej, ponieważ bohaterami są realni ludzie. Oni nie kreują swojego wizerunku, oni się prezentują. Jednakże, podobnie jak to opisała Bardijeuska, od ich indywidualnych cech - głosu, sposobu wypowiedzi oraz ekspresji zależy to, jak są postrzegani. Opisując sztukę radiową w Polsce, Aneta Wójciszyn-Wasyl zauważa:

Słowo radioue u pieruszej kolejności rozpatrujemy na poziomie brzmienia, zuracając uwagę na ton i barwę. Ta warstwa jest już sygnałem znaczenia, a zarazem podlega ocenom estetycznym. Daje słuchaczowi podstawową możliwość identyfikacji osoby mówiącej: kobieta - mężczyzna, stary - młody oraz charakterystyki i klasyfikacji waloróu głosouych: niski, ciepły, głęboki, piskliwy, ostry, nieprzyjemny8.

Sposób wypowiedzi, głos, gest foniczny decydują o ostatecznym wyobrażeniu postaci. Sposób wypowiedzi może zdradzać pochodzenie mówiącego (gwara, slang, wyszukane słownictwo), jego charakter (nerwowość, niepewność, dynamiczność), poziom edukacji, a nawet chwilowy nastrój. Jest tak ponieważ „każdy z nas posługuje

\footnotetext{
${ }^{6}$ Częściowo to zagadnienie zostało opisane w: M. Białek, Polski reportaż radiowy, op. cit., s. 118-122. Niniejsze opracowanie prezentuje temat z szerszej perspektywy badauczej.

7 S. Bardijewska, Nagie słowo. Rzecz o stuchowisku, Elipsa, Warszawa 2001, s. 66.

${ }^{8}$ A. Wójciszyn-Wasyl, Sztuka radiowa w Polsce i jej krytyka do 1939 roku, Wydaunictuo KUL, Lublin 2012, s. 102.
} 
się własnym językiem osobniczym, który charakteryzuje się częstością użycia pewnych wyrazów, unikaniem innych, skłonnością do budowania zdań w jakiś szczególny sposób”. Natomiast głos, który staje się „znakiem ikonicznym postaci wyrażonym fonicznie" ${ }^{10}$, niesie ze sobą dodatkowe znaczenia.

Uczestnicząc u budowaniu postaci - pisze Sława Bardijeuska - głos uyodrębnia je i określa, stwarza ich głosowy portret. Cechy fizyczne głosu wskazują na płeć, wiek, charakter, pochodzenie, wykształcenie; informują o ich intencjach, wyrażają ukryte myśli bohaterów, zdradzają ich autentyczne uczucia i przeżycia - strachu, złości, niepewności, zadowolenia - niekiedy przeczą wypowiadanym słowom; manifestują ich charakter: nieśmiałość, arogancję, gwałtouność, przymilność, butę; zabarwiają emocjonalnie ich relacje z pozostałymi postaciami, wyrażając na przykład druinę, przyjaźń, wrogość, szacunek, niechęć, pogardę ${ }^{11}$.

Głos sugeruje nam konkretne cechy postaci, do której należy, np.: niski, basowy utożsamiamy z mężczyzną, najczęściej korpulentnym, sopran ze szczupłą kobietą. Tego typu walory wykorzystywane są przez twórców słuchowisk radiowych. Tymczasem w reportażu radiowym takie uproszczenie może okazać się zuodnicze, ponieważ radiowiec bazuje na autentycznych wypowiedziach, buduje opowieść z zarejestrowanych wypowiedzi prawdziwych osób. Dlatego odtwarza rzeczywiste głosy, z uszystkimi ich przymiotami, które czasami bywają mylące. I tak u reportażu Dzień dobry, panie Everest $^{12}$ o suojej pasji mówi pięćdziesięciolatek z młodzieńczym głosem, a tytułowa bohaterka reportażu Mamena - Cyganka z Czarnego Lasu ${ }^{13}$ mówi męskim głosem, że jest kobietą, można się zorientować zaś dopiero, gdy użyje żeńskiej formy czasownika.

Przywołane rozważania sygnalizują, w jaki sposób dźwiękowo jest tworzona postać foniczna. Na jej ostateczny kształt składają się elementy osobnicze, jak sposób wypowiedzi i brzmienie głosu. Do tych elementów należy dodać także gest foniczny, którym są wszystkie tak zwane dźwięki dodatkowe, pozajęzykowe, tworzące warstwę awerbalną. Gest foniczny jest audialnym odpowiednikiem gestu mimicznego i stanowi bardzo sugestyuny środek ekspresji ${ }^{14}$. Tak dźwiękowo skonstruowana postać foniczna funkcjonuje w opowieściach radiowych. Warto jednak zastanowić się, w jaki sposób jest ona przedstawiana $u$ reportażu. Jak już zostało zasygnalizowane we wstępie, identyfikacja bohatera odbywa się $\mathrm{w}$ trojaki sposób. Pieruszy z nich to prezentacja przez wypowiedzi pozostałych uczestników zdarzeń.

Prezentacja uynikająca z uypowiedzi uczestników reportażu. Identyfikacja bohatera wynikająca z narracji jest najczęściej używanym sposobem uprowadzenia i dookreślenia postaci. Podczas montażu, reportażysta u taki sposób zestawia ze sobą

\footnotetext{
${ }^{9}$ Ibidem.

10 Kaziów, Ikonofonia, „Teatr” 1972, nr 23/24, s. 29-30.

11 S. Bardijeuska, op. cit., s. 57.

12 A. Walewicz, Dzień dobry, panie Everest, Program III Polskiego Radia 1998.

13 C. Borowik, Mamena - Cyganka z Czarnego Lasu, Polskie Radio Lublin 1998.

${ }^{14}$ Do gestóu fonicznych zaliczamy np.: chrząknięcia, łkanie, chichot, uydmuchiwanie dymu papierosowego, zob.: J. Mayen, O stylistyce utworów mówionych, Zakład Narodowy im. Ossolińskich Wydawnictuo PAN, Wrocław 1972, s. 97-111.
} 
wypowiedzi występujących osób, aby słuchacz jednoznacznie został poinformowany, kim jest bohater. Czasem ten sposób identyfikacji przypomina prezentację formalną, podczas której wymienione zostają imię i nazwisko wprowadzanej postaci. Różnica polega jednak na tym, że przedstawiana osoba jest nieobecna $\mathrm{w}$ trakcie prezentacji, zostaje tylko przywoływana podczas rozmouy o niej. To popularny zabieg konstrukcyjny, uykonywany na etapie montażu, kiedy dziennikarz „skleja” ze sobą dwa fragmenty: pieruszy zawierający identyfikację postaci i drugi - wypowiedź przedstawionej osoby. Takie zestawienie sprawia, że odbiorca bez trudu rozpoznaje bohatera, o którym była mowa we wcześniejszym fragmencie. Zna już jego nazwisko, często także profesję, a do tych informacji dochodzi warstua dźwiękowa, dzięki której z danymi personalnymi utożsamia brzmienie głosu. Ta bilateralność umożliwia jednoznaczną identyfikację bohatera.

Taki sposób prezentacji zastosowała Beata Cichoń u reportażu Czarna prawda ${ }^{15}$. W jej nagraniu mamy dwóch bohaterów: właściciela zamkniętej kopalni i mieszkańców Wałbrzycha, którzy utrzymują się z nielegalnego wydobywania węgla. Ten drugi bohater - lokalna społeczność - jest anonimowy. Dziennikarka rezygnuje z przedstawiania poszczególnych osób. Dla słuchacza wystarczające jest identyfikowanie kolejnych postaci jako części zbiorowości. Dlatego odbiorca wie tylko to, że mówi kobieta, zdenerwowany, młody mężczyzna lub płaczący emeryt, nie jest istotne, jak oni mają na imię. W tej opowieści są bezimienną zbiorowością, którą zjednoczył uspólny problem. Tymczasem po drugiej stronie znajduje się właściciel kopalni, który obawiając się o bezpieczeństwo ludzi, musi zabronić im nielegalnego wydobywania węgla. Właściciel kopalni to konkretny, indywidualny człowiek, dlatego słuchacz poznaje jego imię i nazwisko. Jednakże nie przedstawia się on sam, ani nie robi tego reporterka. Prezentacji, całkiem bezwiednie, dokonuje jedna z rozmówczyń, uypowiadając słowa:

W czerwcu żeśmy zaczęli te prace, które wykonujemy, natomiast bodajże u lipcu albo u połowie sierpnia pokazał się ten pan. Twierdząc, że to jest jego prywatne. [...] Ten pan. Pan Edward Janusz... ${ }^{16}$.

Osoba występująca u reportażu nieświadomie dokonuje prezentacji bohatera, uczestnika sporu. Reportażystka zestawiła te słowa z wypowiedzią przedstawionego mężczyzny: „Jestem uspółułaścicielem, bo jeszcze mam uspólniczkę.... Tak poprowadzony montaż sprawia, że odbiorca z łatwością orientuje się, kto właśnie mówi, jest w stanie zidentyfikować go z imienia i nazwiska, nie ma wątpliwości, że teraz wypowiada się druga strona konfliktu.

Często reportażyści radiowi dokonują prezentacji postaci u sposób pośredni. Korzystają przy tym z nagrań reporterskich, relacjonujących przebieg konkretnych zdarzeń (np.: uroczystości, debaty, zebrania), w których wymieniane jest imię lub nazwisko głównego bohatera. Wówczas dodatkowe dookreślanie nie jest konieczne,

${ }_{15}$ B. Cichoń, Czarna prawda, Radio Wrocław 2001.

${ }^{16}$ Ibidem. 
albowiem z akcji wynika, o kim będzie mowa. W taki sposób uprowadzili do opowieści dźwiękowej swojego bohatera autorzy reportażu Orzeł $i$ reszk $k a^{17}$. Rozpoczyna się on typouym nagraniem reporterskim z obrad sejmowych, podczas których posłowie głosują nad decyzją o ustanowieniu roku 2013 rokiem Jana Czochralskiego. Następnie o naukowcu wypowiadają się uczniowie szkoły podstawowej. Dopiero po tym uprowadzeniu pojawia się narracja odautorska, w której dziennikarze wyjaśniają, o kim będzie ta opowieść i jakie są powody podjęcia tego tematu. Tego typu prezentacja głóunego bohatera jest często stosowana w dziełach audialnych, szczególnie w reportażach historycznych, gdzie główny bohater pojawia się tylko we wspomnieniach i materiałach archiwalnych. W tym przypadku mamy do czynienia z prezentacją sytuacyjną, wykorzystującą wypowiedzi innych uczestników reportażu.

Wskutek konwergencji mediów reportaż radiouy ewoluował, nastąpiło zacieranie granic pomiędzy dokumentem a słuchowiskiem. Z formy typowej dla polskiej szkoły reportażu (która charakteryzowała się całościowym, autentycznym zapisem dźwiękowym) przeobraził się w feature (znany z radiofonii zachodnioeuropejskich), łączącej w sobie faktyczne nagrania reporterskie i elementy fikcyjne. Oznacza to, że narracji reportażowej towarzyszą realizacje słuchowiskowe, do tej pory znane tylko z teatru radiouego. Reportażyści świadomie kreują możliwe sceny, stanowiące ich wyobrażenia zdarzeń historycznych. Taki sposób fabularyzacji dokumentu umożliwia także prezentację uczestników opowieści. W tym przypadku reportażysta kreuje sceny, podczas których osoby w nich występujące dokonują przedstawienia głównych bohaterów. Autor, jawiący się tu jako kreator zdarzeń, rozpisuje narrację intencjonalnie, wyznaczając konkretnym postaciom zadanie poinformowania, o kim jest mowa w dalszej części dokumentalnej. W taki sposób postąpiła Patrycja Gruszyńska-Ruman, tworząc reportaż WiNna nieWiNna ${ }^{18}$. Już na początku opowieści zostaje podane imię i nazwisko głównej bohaterki. Dzieje się to podczas odegranej, na potrzeby reportażu, sceny z procesu sądowego. Całe nagranie zaczyna się od słów:

Proszę ustać! Oskarżam Rachwałową Stanisławę, córkę Karola i Emilii, urodzoną 29 kuietnia 1906 roku w Rudkach, województwo lwouskie, zamieszkałą u Krakowie, ulica Sobieskiego 5, Polkę, bez zajęcia, bez majątku, ze średnim uykształceniem, niekaraną, o to że [... $]^{19}$.

Dzięki takiemu rozwiązaniu - realizacji słuchowiskowej stylizowanej na autentyczne nagranie z procesu sądowego, podczas którego uymienione zostają pełne dane personalne głównej bohaterki - odbiorca już w pierwszych minutach reportażu zostaje poinformowany, o kim będzie opowieść. $W$ dalszych częściach realizacji ponounie kilkakrotnie powtarza się to imię i nazwisko, jednak tym razem prezentacja wynika z wypowiedzi uczestników reportażu.

\footnotetext{
${ }_{17}$ M. Walentyn, M. Słobodzian, Orzet $i$ reszka, Radio PiK u Bygdoszczy 2013.

${ }^{18}$ P. Gruszyńska-Ruman, WiNna nieWiNna, Studio Reportażu i Dokumentu Polskiego Radia 2008.

${ }^{19}$ Ibidem.
} 
Prezentacja uynikająca z uypowiedzi reportera. Kolejnym sposobem na przedstawienie uczestników reportażu jest wykorzystanie przez reportażystę określonych sytuacji, akcji i dialogów, podczas których autor wymienia imię i nazwisko bohatera. Taka prezentacja brzmi bardzo naturalnie. Słuchacz szybko orientuje się, kto za chwilę będzie mówił, jednocześnie poznaje przedstawianą postać w działaniu. Tego typu identyfikacja najczęściej następuje w reportażach interwencyjnych, kiedy dziennikarz występuje jako rzecznik jednej ze stron. W taki sposób postępują poznańskie dziennikarki, Marii Blimel i Wandy Wasileuskiej u reportażu Bez motywacji ${ }^{20}$. Do informowania o tym, kto za chwilę będzie się wypowiadał, autorki wykorzystują fragmenty rozmów telefonicznych. W reportażu brzmi to następująco:

- Urzad Generalnego Konserwatora.

- Maria Blimel, Radio Mekury.

- Zaraz będę taczyć z panem Konserwatorem.

- (męski głos) Halo?

- Czy z panem Markiem Rubnikowiczem rozmawiam?

- Tak, stucham panią ${ }^{21}$.

To typowy i popularny zabieg radiowy, charakterystyczny dla dziennikarstua informacyjnego, wykorzystywany także w reportażach radiouych. W przywołanym przypadku autorka przez umieszczenie początku nagranej rozmowy telefonicznej przedstawiła słuchaczom suojego rozmówcę i określiła stanowisko, jakie on sprawuje. Należy oczywiście pamiętać, że ten fragment został poddany selekcji i zmontowany w taki sposób, aby znalazły się w nim tylko najistotniejsze informacje - nazwisko rozmóucy i funkcja, jaką pełni. Podobna sytuacja komunikacyjna może zaistnieć także $w$ innych okolicznościach, między innymi podczas rozmouy bezpośredniej lub omawianiu problemu z innymi stronami konfliktu. Wyróżnikami tego sposobu identyfikacji są aktywność reportera i jego osobiste zaangażowanie (włącznie z obserwacją uczestniczącą) w zdarzenia.

Innym sposobem dokonania formalnej prezentacji bohatera jest wykorzystanie narracji odautorskiej. Oznacza to, że do nagrania głównego, reporterskiego, włączone zostają partie komentujące prezentowane zdarzenia. Najczęściej stanowią je refleksje autora, dograne przez niego samego, $u$ trakcie realizacji reportażu ${ }^{22}$. Narracje odautorskie mogą zawierać osobiste refleksje dziennikarza, wyjaśnienia, jaka jest geneza poustania dokumentu, a także poinformowania, kim jest bohater opowieści. Tak zrobili autorzy reportażu Adwokat ulicy ${ }^{23}$, których opowieść rozpoczyna się od rozbudowanej narracji jednego z reporterów:

\footnotetext{
${ }^{20}$ M. Blimel, W. Wasileuska, Bez motywacji, Radio Merkury Poznań 2001.

${ }^{21}$ Ibidem.

${ }^{22}$ Czyli w końcouym etapie pracy nad dokumentem, kiedy następuje zgranie poszczególnych fragmentów.

${ }^{23}$ H. Dedo, W. Kasperczak, Adwokat ulicy, Fundacja Głos Ewangelii 2009.
} 
Calgary. Mój przyjaciel się spóźnia. Dla zabicia czasu sięgam po «Calgary Herald», gazetę pozostawioną przez kogoś na łauce. Na pieruszej stronie duży tytuł: «Art Paułouski, adwokat ulicy uniewinniony». Pawłouski? Brzmi jakoś swojsko. Czy to Polak? Czytam z zaciekawieniem szukając odpowiedzi: «Art. Pawłouski, biznesmen polskiego pochodzenia, adwokat ulicy, jak go nazywają, został oczyszczony ze uszystkich 20 zarzutów, jakie postawiły mu władze miasta Calgary. Dziś przed ratuszem miejskim, w ramach protestu przeciu łamaniu praw obywatelskich, odbędzie się pokojowa demonstracja zorganizowana przez Kościół Ulicy». Godzinę później jestem przed ratuszem²4.

Po tym uprowadzeniu pojawia się głos osoby, która głośno protestuje przeciuko działaniom władz miasta, wyraźnie staje w obronie bezdomnych, ludzi zepchniętych na margines życia społecznego. Mimo że jest to wypowiedź po angielsku, słuchacz nie ma wątpliwości, że mówiącym słowa jest główny bohater, Art Pawłouski. Jest to możliwe dzięki wcześniejszej narracji odautorskiej. W tym przekonaniu odbiorcę utwierdza późniejsza wypowiedź bohatera, udzielona już bezpośrednio reporterowi, po polsku. Identyfikacja głównego bohatera została ułatwiona przez wykorzystanie narracji odautorskiej, którą badaczka reportażu Kinga Klimczak nazywa „słowem wtórnie mówionym"25. W odróżnieniu od dokumentów wykorzystywanych w audialnych formach jako teksty u tekście (listy, pamiętniki, pisma urzędowe, fragmenty literackie) narracja tekstu audialnego nie funkcjonuje jako osobny zapis, przeznaczony do innej formy publikacji, nie może funkcjonować poza dziełem radiouym, dla którego została stworzona. Jak zauważa Klimczak:

Narracja dostarcza oczywiście dodatkowych informacji o fabule, tych, które są niezbędne do ogarnięcia całości struktury opowieści, a których nie dowiedzieliśmy się bezpośrednio od bohatera, ale tym samym przede uszystkim spaja uszystkie elementy. Narracja jest gwarantem płynności opowieści, jej ciągłości i czytelności ${ }^{26}$.

Do narracji ucieka się wielu współczesnych reportażystów ${ }^{27}$, również po to, aby wprowadzić i przedstawić swego bohatera. Tak zrobiła Małgorzata Żerwe, autorka Georgia - okruchy pamięci ${ }^{28}$, rozpoczynając swoją opowieść od słów:

Przy Friedrichstrasse 129, w trzypiętrowym bloku wybudowanym dla enerdouskich prominentów mieszka Georgia Pet. Należała do elity kulturalnej [...] Interesuje mnie Georgia. Podobno mówi po polsku, bo w Warszawie spędziła dzieciństwo. Na pieruszą wizytę nie

${ }^{24}$ Ibidem.

${ }^{25}$ K. Klimczak, Reportaż radiowy o krzywdzie i cierpieniu, Primum Verbum, Łódź 2011, s. $96-98$.

${ }^{26}$ Ibidem, s. 97.

${ }^{27}$ Warto zaznaczyć, że do ok. 2000 roku narracja odautorska u reportażu radiouym była ewenementem traktowanym jako „stylistyczna proteza”, która ratowała tok opowieści oraz tuszowała niedostatki warsztatowe reportera. Po 2000 roku, wskutek konwergencji mediów oraz rozuijającej się uspółpracy z rozgłośniami zachodnimi (w których od lat funkcjonuje feature, łączący u sobie różne formy audialne) twórcy z polskiej szkoły reportażu zaczęli dopuszczać ten sposób uzupełniania narracji.

${ }^{28}$ M. Żerwe, Georgia - fragmenty pamięci, Radio Gdańsk 2006. 
zabieram mikrofonu. Muszę poznać tę starszą panią, której życiorysem można by obdzielić kilka osób ${ }^{29}$.

Dzięki takiemu zabiegoui, wykorzystaniu tekstu napisanego tylko na użytek tej konkretnej opowieści, dziennikarka utrzymała nie tylko spójność narracji, ale przede wszystkim zaprezentowała bohaterkę, podając jej imię i nazwisko, a także upisując ją w określony kontekst historyczno-społeczny. Stało się to możliwe przez wykorzystanie słowa utórnie mówionego w postaci narracji odautorskiej.

Formalna prezentacja bohaterów. Reportażyści radiowi, przy przedstawianiu uczestników zdarzeń, korzystają ze sposobu wypracowanego przez dziennikarzy informacyjnych. Polega on na tym, że najpieru emitowana jest kilkusekundowa wypouiedź bohatera, a następnie reporter własnym głosem przedstawia mówiącego, po czym następuje powrót do mówiącego gościa: wypowiedź bohatera - prezentacja przez reportera - dalsza wypowiedź bohatera. Mimo że jest to sytuacja sztuczna, stuorzona na użytek informacji poprzez montaż, jednak w przekazie radiouym brzmi naturalnie. Z tego sposobu korzystają także reportażyści. Tak zrobiły autorki w przywołanym ucześniej nagraniu Bez motywacji ${ }^{30}$. W początkowej części dokumentu dziennikarki same prezentują występujące osoby. Wymieniają je z imienia i nazwiska, dodając pełnioną przez nie funkcję: „Włodzimierz Łęcki - senator z listy SLD, były wojewoda poznański”; „poseł Marcin Libicki - Prawo i Sprawiedliwość”. Autorki zastosouały tu tradycyjny sposób przedstawiana występujących osób, stosowany przede wszystkim przez dziennikarzy serwisów informacyjnych. Najpieru zostaje uyemitowany fragment uypouviedzi danej postaci, a po paru słowach pojawia się umontowane przedstawienie przygotowane przez dziennikarkę. Podobnie postępuje Jan Smyk w reportażu Gdzie strumyk ptynie... ${ }^{31}$. Rezygnuje jednak z podawania nazuisk, ogranicza się do pełnionej przez rozmówcę funkcji, która uzasadnia jego obecność w reportażu:

Rozmówca: (szelest przeglądanych dokumentów) No wie pan, no...

Reporter: Członek Zarządu miasta Białegostoku.

Rozmówca: ...jemu wszystko przeszkadza. Młodzież przeszkadza, grająca w piłkę, przeszkadzaja mu żaby, przeszkadza mu tam woda..., chyba samo życie jemu przeszkadza ${ }^{32}$.

Ten zapis fragmentu rozmowy reportera z urzędnikiem obrazuje, w jaki sposób montowana jest prezentacja formalna: bohater - reporter - bohater. W tym przypadku, gdy mamy do czynienia z interwencyjnym nagraniem, reportażysta postanowił ograniczyć się do dookreślenia funkcji występujących osób, jednak nie dzieje się to ze szkodą dla opowiadanej historii. Zachowana za to została zasada prezentacji przejęta z dziennikarstwa informacyjnego. W odwrotny sposób użyła tej metody

\footnotetext{
${ }^{29}$ Ibidem.

${ }^{30}$ M. Blimel, W. Wasileuska, op. cit.

31 J. Smyk, Gdzie strumyk płynie..., Radio Białystok 2008.

${ }^{32}$ Ibidem.
} 
autorka reportażu $O$ obrazach $i$ innych takich ${ }^{33}$ - ona najpierw zapowiada osoby występujące w nagraniu, wymieniając ich imiona i nazwiska, a następnie emituje fragmenty wypowiedzi. W ten sposób dziennikarka dźwiękowo zaznaczyła konkretne postaci. Ten prosty zabieg pozwala słuchaczom, już na początku, właściwie zidentyfikować występujących bohaterów. Jednocześnie, odwrotne zastosowanie sposobu prezentacji sprawia, że mamy do czynienia z artystycznym przetworzeniem formuły znanej z dziennikarstwa informacyjnego. To wszystko ma służyć wzmocnieniu funkcji estetycznej dzieła audialnego.

Aby uatrakcyjnić przekaz audialny, reportażyści przyjmują określoną konwencję, do której dopasouują także sposób uprowadzenia bohaterów. Może to być styl teatralny, humorystyczny, filmowy czy jakikolwiek inny, odpowiadający koncepcji autora. Bardzo często zostaje on uyraźnie zaznaczony już na początku opowieści, podczas zapowiadania głównych postaci. Taką właśnie konwencję przyjął Jędrzej Morawiecki w reportażu Kartosz $k a^{34}$. Przywołuje on do odpowiedzi poszczególnych bohaterów, każdego z nich charakteryzując u specyficzny sposób:

Ludmiła Nikołajeuna Kabajewa jest nauczycielką. Kabajewa zebrała sto pięćdziesiąt wiader kartofli. [...] Stanislaw Anatolicz Cziudkurzekow jest dyrektorem departamentu do spraw narodowościouych rządu chakaskiego i jak uszyscy padł ofiarą bitwy za urodzaj. Cziudkurzekow zebrał sześćdziesiąt pięć wiader kartofli. [...] Wowa i Anuszka studiują na uniwersytecie w Abakanie. Żyją razem i nie mają problemów finansouych. Wowa nie zebrał jeszcze kartofli. Wszyscy śmieją się z Wouy. Obiecuje, że pojedzie na daczę za tydzieńn ${ }^{35}$.

Słuchacz otrzymuje „pełną” charakterystykę bohaterów. Ponieważ reportaż mówi o ogólnorosyjskim zbieraniu ziemniaków, reporter, dookreślając swoich rozmóuców, uczynił z nich współczesnych „przodowników pracy”. Jednocześnie, stosując taki rodzaj identyfikacji bohaterów, przedstawia ich słuchaczowi zaraz na początku rozmowy z każdym z nich. Równie zabawną konwencję przyjęli autorzy reportażu Kilka wiosennych mgnień słupka ${ }^{36}$, tworząc „szpiegowską opowieść” rodem z radzieckiego serialu o Stirlizu. Trzymając się opisanej wcześniej zasady prezentacji informacyjnej (uypowiedź bohatera - przedstawienie go przez dziennikarza - dalsza wypowiedź bohatera), uatrakcyjnili ją przez wpisanie jej w określoną konwencję:

(muzyka z serialu «Siedemnaście mgnień wiosny»)

Reporter: Wiosna była zimna tego roku i choć powinny się już pojawiać pierwsze jej mgnienia to żadne, z siedemnastu mgnień, na razie się nie pojawiało. (chlupot wody) Bohater: To jest południowy stok, tu byto pięknie, suchutko ale dzisiaj tak napaprato, że nie wiem... (chlupot wody)

\footnotetext{
${ }^{33}$ A. Łapkiewicz-Kalinouska, O obrazach i innych takich, Program II Polskiego Radia 2016.

34 J. Morawiecki, Kartoszka, producent niezależny 1998.

${ }^{35}$ Ibidem.

${ }^{36}$ H. Bogoryja-Zakrzeuska, E. Zozuń, Kilka wiosennych mgnień słupka, Studio Reportażu i Dokumentu Polskiego Radia 2004.
} 
Reporter: Jan Mytkoś, chętnie zasiadłby w swoim fotelu przy kominku, w swoim domu $w$ Szczawnicy by czekać $w$ spokoju na pierwsze mgnienia wiosny ale były rzeczy, które spokoju mu nie dawaty. Po pierwsze nie miat kominka, po drugie nie miał fotela i po trzecie, chyba najważniejsze, nie miał owego domu... (muzyka z serialu $)^{37}$.

Reporter dokonał formalnej prezentacji bohatera, wymienił jego imię i nazwisko, określił kontekst uydarzeń, jednak przyjęta u tym przypadku konwencja sprawia, że całość nabrała żartobliwego charakteru. Zarazem podstawowy cel takiego zabiegu został osiągnięty - postać głównego bohatera została dźwiękowo zaznaczona, fonicznie dookreślona, a odbiorca akustycznie go zidentyfikował.

Prezentacja formalna z przedstawieniem wynikającym z wypowiedzi reportera została ciekawie połączona u reportażu Trzej przyjaciele z boiska ${ }^{38}$. Reporterka pyta jednego z bohaterów reportażu: „Kim jest Wolfgang Templin? [...] Kim jest Wołodymyr Pawliw?”. Za każdym razem słyszy tę samą odpowiedź: „Moim przyjacielem”. W tym przypadku przedstawienie bohaterów reportażu wynika z wypowiedzi reportera. Jednakże $w$ dalszej części opowieści zostaje ona uzupełniona przez prezentację formalną w postaci narracji odautorskiej, stylizowanej na wzór piosenki o tym samym tytule co reportaż. A zatem słyszymy od dziennikarki:

Jeden rodem jest $\mathrm{z}$ miasta Jeny u byłej NRD, drugi rodem jest z miejscouości Rudki w obwodzie lwouskim u byłym Związku Radzieckim, trzeci rodem jest ze Szczecina u byłej PRL. Trzej przyjaciele z boiska - Wolfgang, Wołodymyr i Andrzej, ich boisko to Europa Wschodnia $[\ldots]^{39}$.

Kolejnym typem formalnego przedstawienia bohatera reportażu jest autoprezentacja. Ten sposób identyfikacji także został przejęty od dziennikarzy informacyjnych. Otóż proponują oni suoim rozmóucom, aby przedstawili się sami, ułasnym głosem. Wóuczas interlokutor wymienia imię i nazwisko, czasem dodając pełnioną funkcję, następnie dziennikarz wmontouuje tę prezentację przed uypowiedzią rozmóucy. Reportażyści niekiedy również korzystają z tej możliwości. Tak zrobiła Hanna Wilczyńska-Toczko w reportażu Jak $w$ dom ${ }^{40}$. Jeden z bohaterów, zanim zacznie mówić o swoich podopiecznych, przedstawia się: „Paweł Orliński, trener”. W ten sam sposób reporterka uprowadza dyrektorkę domu dziecka i zaprzyjaźnioną studentkę psychologii. Każda z tych postaci dokonuje autoprezentacji. Oczywiście jest to nienaturalny sposób przedstawiania rozmóuców. W normalnej, codziennej rozmowie nikt nie rozpoczyna wypowiedzi od podania swojego nazwiska i określenia pełnionej funkcji. W relacji informacyjnej taka sytuacja nie razi, wydaje się oczywista i uzasadniona, w reportażu jednak brzmi sztucznie i nienaturalnie. Dlatego jest to najmniej popularna forma prezentacji bohaterów dzieł audialnych.

\footnotetext{
${ }^{37}$ Ibidem.

38 A. Rokicka, Trzej przyjaciele z boiska, Radio Szczecin 2012.

${ }^{39}$ Ibidem.

${ }^{40}$ H. Wilczyńska-Toczko, Jak w domu, Radio Gdańsk 2001.
} 
Anonimowość. Najczęściej jednak bohaterowie reportażu pozostają anonimowi. Dla reportażysty radiowego nazwisko występującego bohatera nie ma znaczenia (oczywiście nie dotyczy to postaci publicznych, pouszechnie znanych). Bohater reportażu jest przeważnie dookreślany poprzez swoją pasję, profesję lub stopień zaangażowania w prezentowane wydarzenia (np. jako świadek lub uczestnik zdarzeń), wówczas dla dookreślenia postaci najistotniejsze okazują się cechy osobnicze, takie jak: głos i sposób wypowiedzi. Na ich podstawie słuchacz buduje sobie obraz uystępującej osoby (stary, młody, nędzarz, biznesmen), natomiast bohater reportażu staje się istotny jako reprezentant określonej postauy lub grupy (zawodowej, społecznej). Jest wiarygodny nie dzięki imieniu i nazwisku, ale poprzez swoją dźwiękową obecność. Słuchacze poznają go poprzez określenie uykonywanej profesji, stopień zaangażowania u przedstawione wydarzenia, nie poznają jednak jego danych personalnych.

W większości reportaży dźwiękouych bohaterowie pozostają anonimowi, ponieważ w przypadku dzieła audialnego liczy się sama historia, jej uniwersalność i ponadczasowość. W realizacjach radiowych możemy usłyszeć uspomnienia ludzi różnych profesji, między innymi: emerytowanego taksówkarza (Wcią̇ dzwoni o 10-tej ${ }^{41}$ ), samotnego rolnika (Ja też chcę być Małyszem ${ }^{42}$ ), młodego rapera (Nieidealna piosen $k a^{43}$ ), sfrustrowanych górników (Zło czai się na dole ${ }^{44}$ ); bohaterów w szczególnym momencie swojego życia, między innymi: zmagających się z ciężką chorobą (Trzeba walczyćt5), osamotnionych (Wdowa $\left.{ }^{46}\right)$, walczących z uzależnieniem (Piekto-Niebo $\left.{ }^{47}\right)$. Tego typu przykłady można mnożyć, u zależności od obszaru zainteresowań reportera i wyboru tematu reportażu. Osobną grupę stanowią anonimowi bohaterowie, interesujący ze względu na specyficzną społeczność, którą reprezentują, np.: siostry zakonne (Kuszenie siostry Ireny ${ }^{48}$ ), więźniowie (Żeby było jak dawniej ${ }^{49}$ ), subkultury (Blok moim domem $^{50}$ ), we wszystkich tych przypadkach mamy do czynienia z postaciowaniem pośrednim, które zgodnie z teorią Henryka Markiewicza jest jednym ze sposobów dookreślenia bohatera: „Postaciowanie bezpośrednie to nazywanie uprost ułaściuości postaci narracyjnej. Postaciowanie pośrednie to podawanie informacji, z których te właściwości można uywnioskować" ${ }^{1}$. Zgodnie z tym, w reportażach radiouych (zwłaszcza $w$ formach monologowych, gdzie najistotniejszy jest bohater, jego przeżycia i spostrzeżenia), bardzo często mamy przykłady postaciowania pośredniego, czyli prezentowanie uczestnika nagrania poprzez jego działanie.

${ }^{41}$ M. Słobodzian, Wciąż dzwoni o 10-tej, Radio PiK Bydgoszcz 2008.

${ }^{42}$ M. Kamiński, Ja też chcę być Małyszem, Radio Lublin 2003.

43 A. Dudzińska, Nieidealna piosenka, Radio Katowice 2014.

${ }^{44}$ A. Sekudewicz, A. Dudzińska, Zło czai się na dole, Radio Katowice 2004.

${ }^{45}$ H. Bogoryja-Zakrzeuska, Trzeba walczyć, Studio Reportażu i Dokumentu Polskiego Radia 2011.

46 A. Sekudewicz, Wdowa, Radio Katowice 2001.

47 C. Galek, Piekto-Niebo, Radio Zachód Zielona Góra 2008

${ }^{48}$ I. Linkiewicz, Kuszenie siostry Ireny, Radio Zachód Zielona Góra 1998.

${ }^{49}$ M. Kapella, S. Wypych, Żeby było ja dawniej, Radio Szczecin 2005.

50 A. Trofimiuk, A. Bajguz, Blok moim domem, Radio Białystok 2001.

${ }^{51}$ H. Markiewicz, Wymiary dzieła literackiego, op. cit., s. 156. 


\section{Podsumowanie}

Niewidzialność przekazu radiowego narzuciła twórcom dzieł audialnych wypracowanie akustycznych środków wyrazu, które umożliwiają identyfikowanie występujących bohaterów. Opisując słuchowiska radiowe Joanna Bachura, stuierdza:

Warto zaznaczyć, iż u dramaturgii fonicznej o istnieniu postaci, o jej swoistym rozwoju w warstuie zdarzeń fabularnych, rozwoju osobowościowym, emocjonalnym - decyduje słowo, ale słowo wzmocnione dźwiękiem, muzyką, całą kuchnią akustyczną̨ $a^{52}$.

Owa „kuchnia akustyczna” jest niewątpliwie pomocna w kreowaniu obrazów wyobrażeniouych, bez których zaistnienie dzieła audialnego byłoby niemożliue. Niemniej dodatkowym wyzwaniem dla radiowców stało się samo wprowadzenie bohatera oraz jego identyfikacja. Jak wcześniej opisano, przedstawienie postaci może nastąpić w sposób bezpośredni, wynikające z wypowiedzi innych uczestników opowieści, a także u sposób pośredni, poprzez prezentację sytuacyjną, która także uykorzystuje wypowiedzi innych osób występujących w reportażu. Prezentacja sytuacyjna może być afikcjonalna (wówczas mamy do czynienia z nagraniem reporterskim) lub fikcjonalna (kiedy do reportażu włączane są partie słuchowiskowe). Kolejny sposób identyfikacji bohatera to przedstawienie go przez reportera. W tym przypadku również uykorzystywane są zdarzenia, sytuacje dynamiczne, w których dziennikarz jest obserwatorem uczestniczącym. Inną metodą dookreślenia postaci jest narracja odautorska, która poustała wyłącznie na użytek reportażu i nie funkcjonuje poza nim. Jest to zabieg stylistyczny coraz bardziej popularny u polskim reportażu. Sprawia, że możliwym staje się zaprezentowanie bohatera z imienia i nazwiska, a także opisanie jego stanów emocjonalnych, przekazanie własnych wątpliwości co do postaci, czy też uyjaśnienie genezy poustania opowieści. Poza tymi dwoma sposobami przedstawienia uczestników reportażu istnieje jeszcze prezentacja formalna. Pod tym pojęciem kryje się sposób identyfikowania zapożyczony z serwisów informacyjnych, którego schemat można zapisać jako: wypowiedź bohatera - przedstawienie przez reportera - dalsza wypowiedź bohatera. Zdarza się, że prezentacje formalne poddawane są stylizacji, której najczęściej towarzyszy narracja w określonej konwencji (np. szpiegouskiej, kabaretowej, kościelnej). Mało popularnym w reportażu, jednak czasami stosowanym, sposobem na przedstawienie uczestników jest autoprezentacja. To kolejny sposób zaczerpnięty z dziennikarstwa informacyjnego, jednak ze względu na swoją sztuczność jest on niechętnie używany u twórczości radiowej. Należy wyraźnie zaznaczyć, że często w jednym reportażu łączone są różne formy prezentacji. Użycie jednej z nich nie wyklucza możliwości skorzystania z innej, u dalszej części rozwijającej się opowieści. Najczęściej jednak bohaterowie reportaży pozostają anonimowi. Dzieje się tak ponieważ dla reportażysty najważniejsza jest opowiadana przez nich historia.

${ }_{52}$ J. Bachura, Odsłony wyobraźni. Wspótczesne stuchowiska radiowe, Wydawnictuo Adam Marszałek, Toruń 2012, s. 188. 
Monika Białek

\section{Bibliografia}

Bachura J., Odsłony wyobraźni. Współczesne słuchowiska radiowe, Wydawnictuo Adam Marszałek, Toruń 2012.

Bachura J., Pawlik A., Wtórna wizualność sztuki radiowej [w:] E. Pleszkun-Olejniczakowa, J. Bachura, A. Pawlik, Dwa teatry. Studia z zakresu teorii i interpretacji sztuki stuchowiskowej, Wydawnictuo Adam Marszałek, Toruń 2011, s. 444-457.

Bardijeuska S., Nagie słowo. Rzecz o stuchowisku, Elipsa, Warszawa 2001.

Białek M., Polski reportaż radiowy. Wybrane zagadnienia, Wydawnictwo Naukowe Scriptorium, Poznań-Opole 2010.

Białek M., Reportaż radiowy jako dzieto sztuki audialnej, czyli o radiowych środkach wyrazu [w:] Media, biznes, kultura, red. J. Kreft, R. Stopikouski, Wydawnictwo Marpress, Gdańsk 2011, s. 28-36.

Gołaszeuska M., Estetyka pięciu zmysłów, WN PWN, Warszawa-Kraków 1997, s. 19.

Kaziów M., Ikonofonia, „Teatr” 1972, nr 23/24, s. 29-30.

Klimczak K., Reportaż radiowy o krzywdzie i cierpieniu, Primum Verbum, Łódź 2011.

Markiewicz H., Radio, „świat z dźwięków” [w:] Dziennikarstwo i świat mediów, red. Z. Bauer, E. Chudziński, Cracovia, Kraków 1996, s. 70.

Markiewicz H., Wymiary dzieła literackiego, TAiWPN Universitas, Kraków-Wrocław 1984.

Mayen J., O stylistyce utworów mówionych, Zakład Narodowy im. Ossolińskich Wydawnictwo PAN, Wrocław 1972.

Mayen J., O twórczości radiowej, „Prasoznawstwo” 1956, nr 1, Zeszyty Naukoue Uniwersytetu Warszauskiego, s. 33-74.

Mayen J., Radio a literatura, Wiedza Pouszechna, Warszawa 1965.

Pisarek W., Retoryka dziennikarska, Ośrodek Badań Prasoznawczych RSW „Prasa, Książka, Ruch", Kraków 1975, s. 131.

Pleszkun-Olejniczakowa E., Bachura J., Pawlik A., Dwa teatry. Studia z zakresu teorii i interpretacji sztuki stuchowiskowej, Wydawnictwo Adam Marszałek, Toruń 2011.

Wójciszyn-Wasyl A., Sztuka radiowa w Polsce i jej krytyka do 1939 roku, Wydawnictuo KUL, Lublin 2012.

\section{Reportaże radioue}

Blimel M., Wasilewska W., Bez motywacji, Radio Merkury Poznań 2001.

Bogoryja-Zakrzewska H., Trzeba walczyć, Studio Reportażu i Dokumentu Polskiego Radia 2011.

Bogoryja-Zakrzeuska H., Zozuń E., Kilka wiosennych mgnień słupka, Studio Reportażu i Dokumentu Polskiego Radia 2004.

Borowik C., Mamena - Cyganka z Czarnego Lasu, Polskie Radio Lublin 1998.

Cichoń B., Czarna prawda, Radio Wrocław 2001.

Dedo H., Kasperczak W., Adwokat ulicy, Fundacja Głos Ewangelii 2009.

Dudzińska A., Nieidealna piosenka, Radio Katowice 2014.

Galek C., Piekto-Niebo, Radio Zachód Zielona Góra 2008.

Gruszyńska-Ruman P., WiNna nieWiNna, Studio Reportażu i Dokumentu Polskiego Radia 2008.

Kamiński M., Ja też chcę być Matyszem, Radio Lublin 2003.

Kapella M., Wypych S., Żeby byto ja dawniej, Radio Szczecin 2005.

Linkiewicz I., Kuszenie siostry Ireny, Radio Zachód Zielona Góra 1998.

Łapkiewicz-Kalinouska A., O obrazach i innych takich, Program II Polskiego Radia 2016.

Morawiecki J., Kartoszka, producent niezależny 1998. 


\section{Dźwiękowa identyfikacja bohaterów w reportażu radiowym}

Rokicka A., Trzej przyjaciele z boiska, Radio Szczecin 2012.

Sekudewicz A., Wdowa, Radio Katowice 2001.

Sekudewicz A., Dudzińska A., Zto czai się na dole, Radio Katowice 2004.

Słobodzian M., Wciąż dzwoni o 10-tej, Radio PiK Bydgoszcz 2008.

Smyk J., Gdzie strumyk ptynie..., Radio Białystok 2008.

Trofimiuk A., Bajguz A., Blok moim domem, Radio Białystok 2001.

Walentyn Ż., Słobodzian M., Orzet i reszka, Radio PiK u Bygdoszczy 2013.

Walewicz A., Dzień dobry, panie Everest, Program III Polskiego Radia 1998.

Wilczyńska-Toczko H., Jak w domu, Radio Gdańsk 2001.

Żerue M., Georgia - fragmenty pamięci, Radio Gdańsk 2006. 